It is to be hoped, therefore, that immediate steps will be taken to adopt the suggestions of the Advisory Council. The report refers with satisfaction to the general work of the Museum and the special exhibitions which have become a feature of its activities. With the advance of discovery, invention and industry it is unavoidable that the collections should increase rather rapidly, and there is every justification for the demolition of the old centre galleries and their re-erection in keeping with the eastern block.

\section{Research on Potatoes}

DURING the annual general meeting of fellows of the National Institute of Agricultural Botany at Cambridge on July 21, the chairman of the Council, Dr. R. N. Salaman, reviewed the Institute's work on potatoes during the past twenty years. The tests for immunity from, or susceptibility to, wart disease, has materially assisted the breeders' efforts towards raising only immune varieties; the critical examination of the many thousands of seedlings entered for these tests has led to a rapid elimination of useless varieties, and the work of the Potato Synonym Committee has resulted in the almost complete elimination of synonyms. The large-scale demonstrations at the Potato Testing Station, Ormskirk, have proved that it is possible for farmers in Great Britain to grow and maintain virus-free stocks for seed purposes. He estimated that the loss in yield in Great Britain alone from the use of virus-infected stocks for seed purposes is in the nature of a million tons a year. With regard to potato breeding, Dr. Salaman thinks it very unlikely that any outstanding varieties will be produced until new methods are introduced; breeding stocks require the injection of fresh blood by the use of wild tuber-bearing species of Solanum. In conclusion, Dr. Salaman stressed the importance of reorganizing and regularizing potato seed production, that being the basic element in potato culture and of the utmost importance in time of war. Our immediate need is a scientific organization of the industry from the production of seed at one end of the scale to the dish of potatoes on the table at the other. Virus disease and blight cost the nation about five million pounds a year; loss caused by the former could largely be avoided by the proper organization of the seed trade and further research might well eliminate the latter.

\section{Scientific Aspects of Refrigeration}

ON July 12, a conference on "Refrigeration" organized by the British Association of Refrigeration was held in the rooms of the Royal Society. On the previous day, meetings of the Technical Board and Commissions of the International Institute of Refrigeration were held at which eighteen countries were represented. The first paper to the Conference was presented by Dr. A. K. Balls of the Food Research Division, U.S. Bureau of Chemistry and Soils. It dealt with enzyme action in food products and at low temperatures. In the subsequent discussion Dr. L. J. Harris of the Nutritional Laboratory, Cambridge, Dr. Katherine Coward of the Pharmaceutical Re- search Laboratory, and Miss M. Olliver took part. Prof. Prescott of Boston presented a paper prepared by Messrs. R. R. Jenkins and D. K. Tressler of the N.Y. State Agricultural Experimental Station, Geneva, N.Y., and G. A. Fitzgerald of the Birdseye Laboratories, U.S.A., on vitamin $\mathrm{C}$ in vegetables : storage temperatures for frosted vegetables. Dr. Kidd of the Low Temperature Station, Cambridge, read in abstract a paper by himself and Dr. Moran on atmospheric control in the preservation of foodstuffs.

In the afternoon, the session was opened by a paper by Mr. Edgar A. Griffiths, South Africa, on the design and operation of large gas stoves. Following a brief discussion on air conditioning there were three contributions from Germany. Dr. Plank of Karlsruhe dealt with the ideal comparison cycle of refrigeration for international use. Dr. E. Altenkirch of Berlin read a report on an international unit of refrigeration, and Dr. E. Schmidt of Braunschweig discussed the question of preparing standard tables for the properties of refrigerants. The Conference was presided over by Dr. Ezer Griffiths and Mr. A. R. T. Woods, past-president of the British Association of Refrigeration. The papers in abstract and the discussions are being published in Ice and Cold Storage and other journals.

\section{Leverhulme Research Fellowships}

ThE following Leverhulme research scholarships, among others, have recently been awarded for research indicated: Dr. W. Cule Davies (University College, Cardiff), organic compounds of nitrogen, phosphorus and arsenic ; Dr. S. Goldstein (University of Cambridge), turbulent motion of fluids ; Dr. F. C. Happold (University of Leeds), nutrition of the three types of $C$. diphtherioe in its relation to toxin production; Dr. M. W. Jepps (University of Glas. gow), structure and life-cycles of certain marine Protozoa; Dr. W. H. S. Jones (St. Catherine's College, Cambridge), Greek medicine and Greek thought from 500 to 300 B.c.; A. King (Imperial College of Science and Technology, London), leader of expedition to carry out a biological, geological and physical examination of Jan Mayen Island in the Greenland Sea; D. A. O'Duffy (Bahrein Petroleum Company), lubrication problems at high pressures and temperatures; Dr. O. A. Oeser (St. Andrew's University), the 'combined' method in the social sciences; Dr. G. B. B. M. Sutherland (Pembroke College, Cambridge), application of infra-red spectra to structural problems in chemistry and physics; Dr. W. Taylor (The Polytechnic, London), substitution mechanisms in aliphatic compounds; Dr. B. Thomas (London School of Economics and Political Science), post-War migration of population within the British Empire and as between the Empire and the rest of the world; Dr. W. H. Thorpe (Jesus College, Cambridge), physiology of African tropical Homoptera; R. Wilson (University College, Swansea), nature and position of the singularities of a function in relation to the coefficient theory of its Taylor series. 